\title{
The English Education Research of Tibetan Areas
}

\author{
Xiaokun $\mathrm{Liu}^{1, \mathrm{a}}$, Jian $\mathrm{Zhou}^{2, \mathrm{~b}^{*}}$ and Ning $\mathrm{Cai}^{2, \mathrm{c}}$ \\ ${ }^{1}$ School of Foreign Languages, Northwest University for Nationalities, Lanzhou, China \\ ${ }^{2}$ College of Electrical Engineering, Northwest University for Nationalities, Lanzhou, China \\ alxk0523@163.com, bzhoujianfrank@126.com, ccaining91@tsinghua.org.cn \\ *The corresponding author
}

Keywords: Tibet English education; Cooperative teaching; Layered education mode; Economics

\begin{abstract}
Tibet is located in the southwest of China which has its own unique geographical, cultural and historical characteristics. As well as Tibet stay from the eastern coastal developed areas. According to the upon reasons, Tibet locate English Education has its own unique approach and the difficulties from themselves. However as an English Education Spreader play an important role in Tibet. The locate government should not only produce the feasible measures and profitable policies, but also take care of the students who lack of basic English education in Tibet. Through the development of education to promote the improvement of the Tibet people's humanistic quality, and then to promote the development of locate economic. In some sense, education is a source to strengthen the development of hometown, particularly, in some remote area. Really do that the balanced development of education and economic.
\end{abstract}

\section{Introduction}

The Tibet language has become the local communication of main life for special historical reasons. With the rapid development of economic and society, English language as a third party which has been enrolled in learn course in the Tibet [1]. We should pay more attention to the remote education when the world progress. As an international communication language, mastery of English shows that the community whether follow the steps of international. In Tibet areas which has many religious belief, in order to avoid some unnecessarily trouble so far as to influence the future interest cultivation and produce some negative resist, we can not according to the original materials when we are going to spread English language education [2]. We have to follow the local actual situation when we arrange English education fees and costs. Although English is the intersection of western European and American countries which various aspects of more open avant-garde, but upon these are not applicable to the Tibet education. Thus we need to increase and decrease the right amount to facilitate the most parents and students to accept the importance of the English education. Three language change has become a new problem of language education. How to solve this problem has become the difficult of the modern education too [3, 4].

\section{The Main Modes of the Tibet Areas}

Collaborative Mode. Collaborative education mode is the help of the both side of teachers and students [5], which to carry out activities related to learning. The scope of collaborate learning can cover a lot of contents, such as the preparation before work, learning in the class, the evaluation work of after class. So far, the most teachers who come from Tibet areas always use collaborative mode to teach English language in the class [6]. Through the efforts of both teachers and students to make the better spread of English education in local. Ultimately to achieve the goal of common progress. 


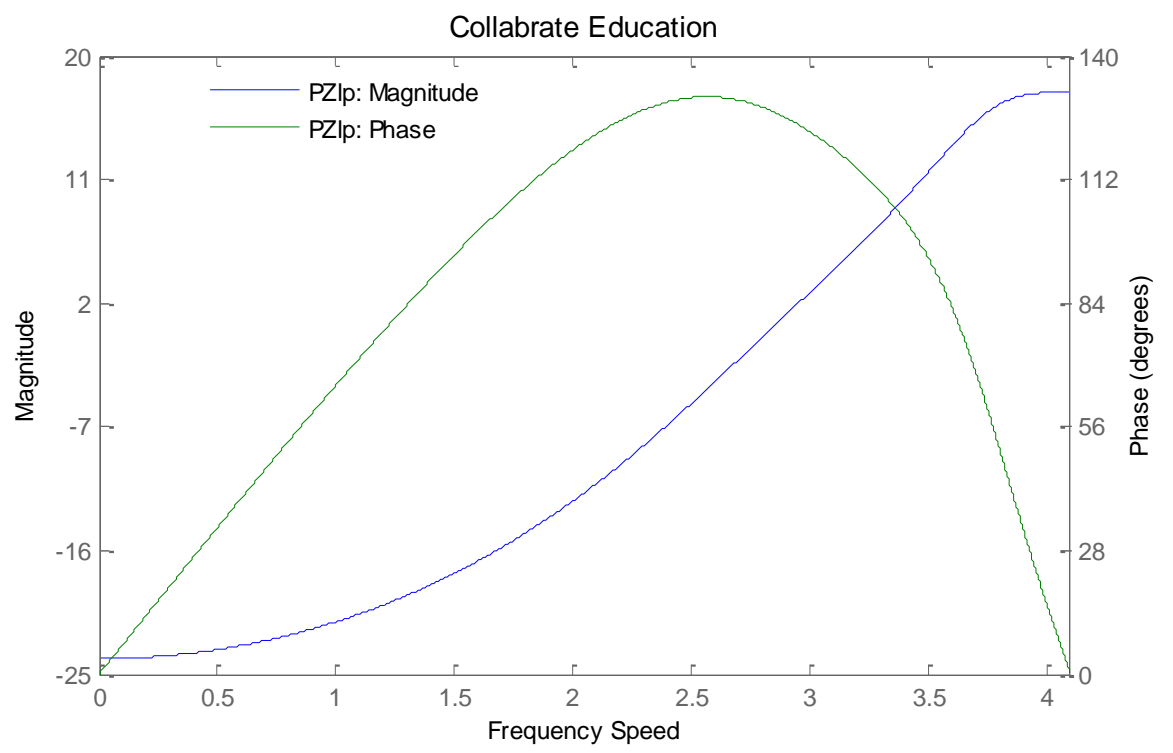

Figure 1. The Curvature of Collaborate Speed

The preparation before class is the most important part of the teaching link [6, 7]. Through the preview can let students understand roughly to the course contents. In addition, refer to the relevant information can also be better expand the knowledge viewpoints of the Tibet students. Let them can know some history about American and England when they are going to learn vocabularies and grammar. The main purpose of collaborate education mode is that enhance the enthusiasm of the Tibet students and cultivate a good habit of study language [8].

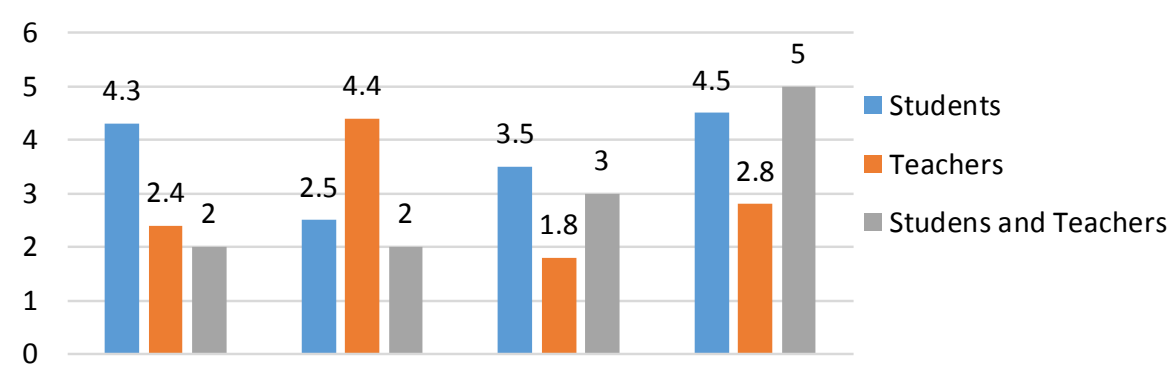

Figure 2. The Histogram of Collaborate Education Mode

\section{The Layered Teaching Mode}

Each region of the gap between students learning ability because of the geographical location of the Tibet. It is make a big challenge for the English teachers when the different ability and different background of the Tibet students [9]. Thus the government should pay more attention to upon problem when the situation were been reaction. After the discussion of the department produced a stratified teaching mode which is a better teaching mode foe the different ability of the Tibet students. Divided into different levels of classes according to their own English level and every classes formulate different complexity [10] and progress of the course in order to let the whole students of the Tibet to control the knowledge as soon as they hope. We can set them to three layered such as junior class, middle class and senior class.

The key idea of our approach is that through different methods and layered to evaluate different students fro Tibet. Why do we lay much emphasis upon this. Several viewpoints might equip us with deeper understanding of what we are heading for. We use software of matlab and supass to evaluate the proportion of the quality of English language education. It is easily to find out which 
produce a better effect on the Tibet students.

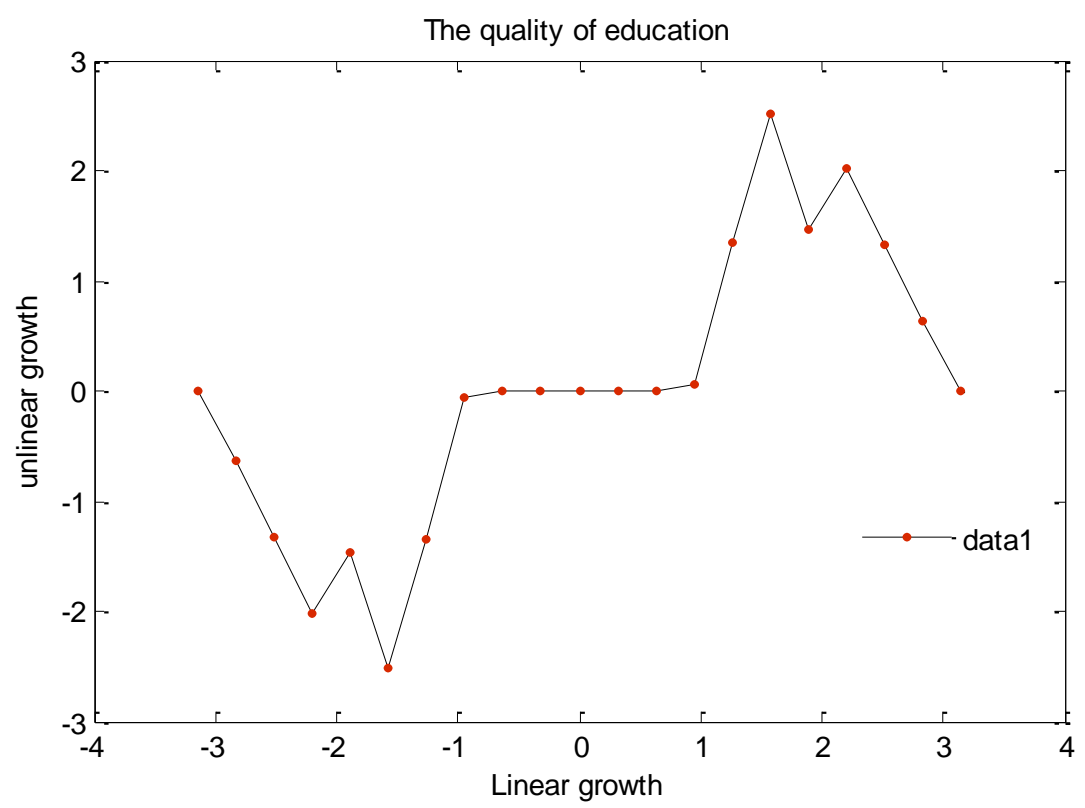

Figure 3. The Chart of quality Effect

\section{Conclusion}

In summary, the Tibet education is a big challenge for the teachers of English education language and the locate government. It is my conviction that only by doing so will we create a warm situation an bask in the happiness journey. Of course, there are many unsolved problems to make an progress change and research. According to a survey made by China Daily $73.23 \%$ of young people from Tibet who have hope the locate government to approve the economic and education quality. At least in theory, we need to redefine the concept and meaning of Tibet education, as well as we need to research how to learn and control new knowledge and for what. Now, with the rapid development of Tibet Economic and informational, all regions are enhancing to improve the English language education. Thus, development of Ethnic education is the top priority. We need pay more attention to the English language education as soon as possible.

\section{References}

[1] N Bertels How Teachers and Researchers Read Academic Articles [J]. Teaching and Teacher Education 19 (7), 2003.

[2] M.J.Wallace. Training Foreign Language Teachers: A Reflective Approach [M]. Cambridge: Cambridge University Press.1991.

[3] J. Harmer: How to Teach English [M].Canada: School Improvement Press.2006.

[4] S.P.Corder Introducing and Applied Linguistics [M].Penguin Books.1973.

[5] Wajnryb \& Ruth. Grammar Dictation and Education [M]. London: Oxford University Press.1990.

[6] Anderson, A. \& Lynch, T. 1988. Listening [M]. Oxford: Oxford University Press.

[7] Anderson, J. R. 1985. Cognitive Psychology and its Implications [M]. New York: W.H. Freeman.

[8] Hughes, A. Testing for Language Teachers. Cambridge: Cambridge University Press, 1989 Ellis, R. 
[9] Understanding Second Language Acquisition. :Oxford University Press, 1985.

[10] James,C. Errors in Language Learning and Use. New York: Longman, 1998.

[11] Nunan,D. The Learner-Centred Curriculum. Cambridge: Cambridge University Press, 1988.

[12] Stern,H.H. Fundamental Concepts of Language Teaching. Oxford: Oxford University Press, 1983. 